\title{
THE GOOD DIE YOUNG
}

\author{
By Monroe M. Stearns
}

From early times the lives of men and women bave been retold by biograpbers to point morals to the living. Sucb was the purpose of the mediaeval saint's life, with its emphasis on the supernatural and the death-bed scene; in the 57 th century the lives of laymen, wbose ways should be followed or avoided, became the subjects of biograpbies aimed to improve the reader. This moral bent, as it appeared in the pious lives of children of the early 1qth century, is illustrated in the following article. Mr. Stearns is a former master of English in the Rutgers Preparatory Scbool and is now teacbing in Westminster Scbool.

HUNDRED years ago the freedom and carelessness of
childhood in America, and England too, was a cause
of more concern than an opposite tendency would be today. Whatever the opinions of Rousseau, Wordsworth, and Emerson, God-fearing, self-righteous, and prosperous families - particularly on this side of the Atlantic-were rather prone to consider their offspring as limbs of Satan. Earnest and eager assaults were made on the infant conscience to lead a life of devotion and prayer before increased years might make a future resolve too difficult and too late. One of the most familiar of these exhortations was the "old-fashioned Sunday" with its double visit to church and restriction of reading matter to the Bible, Pilgrim's Progress, and religious tracts, into which company it is good to learn The Bible in Spain was often allowed to intrude by parents misled by its title.

For the modern generation to enjoy such a day is unthinkable, but children there were who revelled in these Sundays, even some who went so far as to wish that every day in the week were Sunday. If the slippery horsehair of the parlor sofa drove them to desperation, the tears they shed were for their inability to concentrate on their sins, not at the thought that they must desert the pool in the creek or the snow-packed hill. Of Heaven they could not be sure, but of being briefly immortalized in a "Memoir" they could be positive almost beyond the shadow of a doubt.

"Memoirs," to give a generic name to this lugubrious genre of American literature, are the lives of young persons who 
died at an early age after exhibiting notable signs of piety: Memoirs have an importance because they express in popular form the spirit of an era in America which was a time of reckoning, of speculation as to each individual's eventual and ultimate abode, and of preparation for an imminent day of doom. They were read and were designed to be read by children, and because a character is determined by its early experiences, the influence on mature minds of this melancholy childhood reading may partially account for the extremes of personality which marked many of our nineteenth century leaders.

"Memoir of - or the subject's name itself is the title almost always given to these protocols, and no author's name ever appears on the cover or title-page. Often the text reveals the writer as a relative, friend, or minister of the deceased. The period in which these pious children lived may be roughly established as 1800 to $185^{\circ}$ : a very few lingered beyond the latter date, and those few who were born in the eighteenth century missed the turn of the century by no more than seven years at the most. ${ }^{1}$

Perhaps the greatest similarity in different careers is found in the period of childhood, but in these memoirs of the departed young the reader cannot help wondering whether so many children could have had such similar experiences and shared so many thoughts and hopes. It almost seems as if the authors had fitted around the brief existences of their subjects a fabric of incidents which were more the product of their own wishful imagination than an account of actualities. Enough of the children can be identified as having been real to warrant an assumption that the little books were not wholly fictitious, but the often appearing by-line on the title-pages of these memoirs, "Revised by the Committee of Publication," implies that, regardless of the accuracy of the original information, the completed work is somewhat stereotyped. No censure is intended of the devout clergymen and bereaved relatives who wrote of the pious infants, but enthusiasm and ecstasy often transmit their glow to the objects contemplated. Dates of pub-

\footnotetext{
1 These figures do not include the dates of the children whose lives are epitomized in Janeway's $A$ Token for Cbildren, the most famous of all collections of this kind. Since James Janeway lived from 1636 to 1674 , these children of necessity antedated his decease. Neither do the dates include the ten children of the supplement to that book, all of whom died before 1727 .
} 
lication are as much as thirty years beyond the date of the subject's decease, and Time has a way of enhancing fond recollection.

For the lives of these little saints conform to a pattern. They were all of poor parents, and frequently orphans and foundlings, for virtue seemed most of ten to dwell with those of low degree. In school they were precocious and loved learning, invariably possessing "a lively disposition, a very solid mind, together with an unusual quickness of understanding." The qualities of a "sweet, mild, governable temper," a "peculiar affection for parents," and a "high regard for truth" are always emphatically recorded and expanded with many illustrations. If "not above the usual innocent amusements of children," they wouldn't play with liars, hated bad language, and never failed to remonstrate with those of their acquaintance who were untruthful or profane. Small wonder that soon they ceased to care for their playthings, became solitary, and spent their days in prayer, reading the Bible and tracts, and learning verses of Scripture and hymns. Soon, no matter how healthy they had been-a few were admittedly sickly - they were overtaken by disease. The favorite complaints, and indeed almost the only ones mentioned, were consumption, inflammation of the lungs, inflammation of the bowels, and scrofula. Regardless of whether they were ill for a few days or for months, they suffered terrible agonies described in detail. The fear that they would die sinners and be denied the eternal company of God and His angels increased their pain. The minister was sent for, and after long catechizing and confession of guilt, the souls of the sufferers were eased. They then submitted to God's will, either rejoicing that they were going to glory or regretting that they could not live to be missionaries. As their anguish increased, they comforted themselves with Isaac Watts' lines,

Jesus can make a dying bed

As soft as downy pillows are,

While on his breast I lean my head,

And breathe my life out sweetly there.

The last moments drawing near, they summoned their brothers and sisters to the bedside, instructed them to live in virtue and cling to Christ, distributed their Sabbath School prizes among 
them, and expired in the arms of their seldom grief-stricken mothers.

The Rutgers University Library possesses an excellent example of this genre, which is, so far as can be learned, a unique copy. ${ }^{2}$ This Memoir of Samuel $S$. Cope begins with the address to the reader which is never missing from these tracts:

The object in preserving this brief Memoir is not to enlarge the man, but to magnify and extol the power and excellency of Divine grace which so mercifully followed him, and by its leavening virtue, made him what he was. And to present to those into whose hands it may come, the blessed effects of unreserved obedience to its heavenly visitation.

A perusal of further pages reveals that the author is one (or both) of the young man's parents, and the characteristic exaggeration and feeling is thus to be expected, this time expressed in a phraseology which seldom deviates into sentences.

Samuel S. Cope, a member of the Society of Friends, was born the I2th of first month (January), I838. As a child and adolescent, he was retiring and diffident. Careful in choosing his intimates, he found it hard to make friends. Even to those few intimates he had, he never spoke of his own "feelings and attainments": at all times did he mind his own business and think well of all people. Later, as he matured, he investigated other religions than that of the Friends, but his experiences only convinced him that his family's religion was nearest Christ. However, his regeneration was slow, and he was inclined to "put off the work of obedience and dedication to a more convenient season."

His last illness came upon him on December 21, 1866, as the result of an internal injury. In all, he was confined for eleven weeks, enduring "great bodily suffering, wherein he manifested a remarkable degree of Christian patience and resignation. ... His physical agony and suffering at many times appeared to be almost more than his frail earthly tabernacle could endure." Nevertheless he considered his accident a blessing in disguise, for he was able to give up earthly pleasures (one wonders what they could have been) to "seek after the durable riches and treasures of eternity."

"Memoir of Samuel S. Cope, Son of Morris and Ann Cope. "Come unto me, all ye that labour, and are heavy laden, and I will give you rest. Take my yoke upon you, and learn of me: for I am meek and lowly in heart: and ye shall find rest unto your souls." MAT. xi, 28, 29. For private circulation. Philadelphia: William H. Pile, Printer, I867. 
Fearing that his chances of redemption were lost, he called his cousins to his bedside and advised them to take warning by him. However, his father had a message that his son's sins were forgiven, and thereafter Samuel was happy. His mind no longer felt his suffering, being "clothed with the spirit of fervent supplication." He expected to be able to sing around God's throne, and lest the opportunity be denied him by a longer earthly stay, he refused to change his physician-obviously a quack - or to entertain any hope of recovery. Finally, perceiving that his end was near, he called to his friends and family, gathered them around him, and adjured this bedside group "to go to meeting, to be good, and to do many good little things, and you will never regret it." Then, having sent everyone to bed, he quietly breathed his last on 3 Ist of third month (March), I867, aged twenty-nine years, two months, nineteen days.

Collections of these little lives are less frequent than individual tracts, yet several of them exist. The earliest of these is Janeway's $A$ Token for Cbildren, already referred to. Others are Experience Mayhew's Narratives of the lives of pious Indian cbildren who lived on Martba's Vineyard more than one bundred years since (Boston, I829), and The Pleasures of Piety in Youth Exemplified in the Life and Death of Several Cbildren (Boston, I8I9), which contains the lives of twelve little martyrs all below the age of twelve years. These collections are often reprints of the most popular of the individual memoirs, assembled perhaps for purposes of preservation.

The Rutgers University Library possesses a fine example of these anthologies, ${ }^{3}$ surely the largest single one ever made, for it contains one hundred narratives, each one a little more moral than its predecessors. It includes the life of Elizabeth C. Secor, copies of which exist in the Rutgers Library in two other forms: one a tiny fourteen page pamphlet; the other a smaller collection of seven lives all of which occur in the larger collection. ${ }^{4}$ All of these recount the histories of the short-lived members of the Society of Friends both English and American. Thomas Evans, the compiler, doubtless in editorial zeal, took

${ }^{3}$ Examples of Youtbful Piety; principally intended for tbe Instruction of Young Persons. By Thomas Evans. Philadelphia, 1846.

${ }^{4}$ Instances of Early Piety, Designed for tbe Instruction of Cbildren. Philadelphia, n. d. Number 33 of the publications of the Tract Association of Friends. 
some liberties with his source material, and the variations between his and other accounts of the same characters are quite noticeable-a further indication that truth may sometimes have been adjusted to the author's or publisher's requirements.

Closely related to the memoir is the published sermon extolling the life of a departed infant, yet failing to give enough detail to allow of its being called a true Memoir. Such a type is the twenty-page pamphlet in the Rutgers Library which presents a sermon on the life of Miss Dinah Doudney of Portsea, England. ${ }^{5}$ This sermon, we are told, was delivered to an audience of children which was thought to exceed fifteen hundred. The text is taken from the story of Elisha and the Shunamite's son: "Is it well with the child? And she answered, it is well." The address must have been delivered with considerable effect, for every now and then the Rev. Griffin makes a digression, and, probably pointing with a bony finger at a fidgeting youngster, thunders:

You, little boy, that told such a wilful lie the other day, if you should be ill and die, what do you think will become of you? And you, little girl there, who stole the little maid's thimble the other day, and then told a lie to hide the fault, what do you think will become of you? That great boy there, who played truant some time ago, because he would not learn his book, nor say his catechism, and then told his mother he had been to school, what can we think will become of that wicked boy?

Dinah died when she was nine years old. Her mother had preceded her to bliss by four years, and the brief remainder of Dinah's life was devoted to a hope of rejoining her. Dinah was "very much engaged in prayer," especially secret prayer. During the period of anxious waiting in England for Napoleon to cross the Channel, she prayed earnestly for deliverance from him. "If God delivered a city by a woman," she opined, "he could make even such a little creature as I am the means of saving a nation if he pleased."

Dinah "took great delight in reading," and, as in many of the memoirs, there is given a list of the books in which all good children should revel. The usual list of them includes, of course, the Bible. Next to that in order of preference are Foxe's Book of Martyrs, The Pilgrim's Progress, Nicholl's Help to the Reading

' Early Piety; or the History of Miss Dinab Doudney, of Portsea, England, by Reverend Fobn Griffin. Published by the American Tract Society (No. 33). n. d. 
of the Bible, Janeway's A Token for Cbildren, Baxter's The Saint's Rest, and Isaac Watts' hymns. To these Dinah added "Mr. Shrubsole's Christian Memoirs," and "The Life of Mr. Henry Darney."

Each one of Dinah's virtues forms the topic for the nine periods of the address. Her religion began early and lasted till death; her religion was real, not feigned; she prayed continually; she read much; going to church delighted her; the happiness of others and love for them was a great concern; she understood how sinners are to be saved; her death was happy. For with all her virtues, she died on Thursday evening, March 27, I799. Who can doubt, concludes Rev. Griffin, that "Dinah must think it well with her, to be able to talk with Abraham, and Moses, and David, and Paul?" Who indeed can doubt that the tot who fancied herself another Ste. Geneviève would find herself at ease in conversation with that master of intricate thought, St. Paul?

It hardly seems possible that these tiny volumes, crudely printed and cheaply bound in paper, could have been very attractive pieces of reading matter to a reader at any stage of development. Yet read they were, and many examples testify to this. A scrawled signature or a delicately traced inscription of presentation shows ownership. On a few of the illustrations - gloomy woodcuts of deathbed scenes, praying children, and grassy graveyards - fading colors roughly applied bespeak the eternal urge of the child to "crayon." Pothooks and hieroglyphs frequently decorate the slender margins. It is too much to read into mildewed spots the traces of tears of contrition; still a loop of hair or a knot of ribbon affixed to the binding tells clearly enough the sentiment of the owner.

It is to be regretted that so many of these little books have disappeared. A three years' search through the leading libraries of the East has revealed only sixty-six unduplicated examples, yet the catalogue of the American Tract Society-one of the principal publishers of Memoirs-for 1846 gives the titles of seventy-three more. The Rutgers University Library is fortunate to have such excellent and well-preserved examples of the histories of that throng of precocious martyrs whose brief but blessed lives make up a Golden Legend of American innocence. 